\title{
A JPTE, MINT A REGIONÁLIS POLITIKA FELSŐOKTATÁS KÉPZÉSI KÖZPONTJA
}

\author{
(The Janus Pannonius University, as the Centre of Teaching \\ Regional Studies at the University Level)
}

\section{BUDAY-SÁNTHA ATTILA}

\section{Az egyetemi szintũ regionális szakember képzés kezdetei}

A rendszerváltással egyidejủleg megkezdődő demokratizálódási folyamatok hatására, a központi tervezési rendszer megszünésével, a települések, kistérségek, régiók gazdasági és politikai önállóságának és ezzel jảró felelősségének növekedésével elötérbe került, hogy a felmerülő feladatok megoldására csak regionális szemlélettel rendelkezỏ, a regionális politika, tervezés és gazdálkodás eszközeit, intézményeit, alkalmazott módszertanát ismerő szakemberek képesek. A szakember kifejezést azért kell használnunk, mert a területfejlesztési és tervezési feladatok megoldására hivatott regionális tudományok szerves részét képezik a korunk sokoldalú kihívására választ adni kívánó multidiszciplináris tudományoknak, amelyek az alaptudományok ismeretében jól felépített képzési program keretében sajátíthatók el. A regionális tudományok a környezet-gazdaságtanhoz hasonlóan interdiszciplináris tudománynak tekinthetők, amely nagyrészt a más tudományágaktól átvett eszkőzök és módszerek integrált felhasználásával közelíti meg és oldja meg az egyes térségekben felmerüló feladatokat. Erre nemcsak a fejlesztési feladatainknak a korábbinál eredményesebb megoldása, a fejlesztések terén eddig elkövetett hibák elkerülése érdekében van szükség, hanem azért is, mert az EU-hoz való csatlakozásunk a regionális fejlesztés terén nemcsak a korábbinál kedvezőbb lehetőségeket teremt, de egyben a területfejlesztéssel szemben ưj, magasabb szintü követelményeket is támaszt. A gondot eddig sem csak a pénz hiánya jelentette és jelenti még napjainkban sem, hanem azok ágazati szétforgácsoltsága, a fejlesztési tervekben az egyoldalú ágazati szempontok érvényesítése, amelynek következtében a különbỏző fejlesztési elképzelések kioltják egymást, vagy csak rossz hatékonysággal érvényesülnek. Csak egy példaként említem, hogy körültekintó tervezéssel a munkanélküliség kezelésére fordított eszközökből jórészt meg lehetett volna oldani az ország erdósítését, amely a vidéki problémák kezelésében, a környezetvédelmi helyzetben, az ország kultúrállapotban tartásában és a jövőbeni fejlesztési lehetỏségek terén a jelenleginél sokkal kedvezőbb helyzetet teremtett volna.

Mindez előtérbe helyezi a regionális tudományok oktatásának és kutatásának fontosságát. Erre Pécs az országban szinte egyedülálló lehetőségekkel rendelkezik, mert rendelkezésre áll egy 6 karú egyetem, amelyen az összes alapozó jellegủ tudományterületen színvonalas képzés folyik, és Pécsett van a Magyar Tudományos Akadémia Regionális Kutatások Központja és egyik alközpontja, a Dunántúli Tu- 
dományos Intézet is. Nem kevésbé fontos az sem, hogy a regionális oktatás fejlesztését az intézet szakember állománya, vezetői fontos feladatnak tekintik. Megjegyzem, hogy mindenütt, ahol regionális képzés folyik vagy szándéka felmerült - Pécs mellett Győrött, Budapesten, Szegeden és Miskolcon -, a hátteret a Regionális Kutatások Intézetének területi alközpontjai képezik. A pécsi posztgraduális szakon végzett hallgatók szorgalmazták Dunaújvárosban is a képzés beinditását. Ettöl eltér a vidékfejlesztéssel foglalkozó képzés, amely 1994-ben a pécsi nappali képzéssel egyidejúleg indult a Gödöllői Agrártudományi Egyetemen a Gazdasági Agrármérnöki Szak szakirányaként.

Magyarország gazdasági- és tărsadalmi helyzetének változásával egyidejúleg megjelenő területfejlesztési szakképzéssel kapcsolatos igényt elöször a fơhivatásszerüen ezzel a kérdéssel foglalkozó kutatók érzékelték. Ezért Magyarországon a terület- és településfejlesztéssel kapcsolatos szakképzés Terület és településfejlesztési Továbbképző Szak címmel a JPTE Közgazdaságtudományi Kara posztgraduális szakaként az MTA Dunántúli Tudományos Intézetében Pécsett kezdődött el. Ezt kővette a budapesti Eỏtvös Loránd Tudományegyetemen a pécsi kutatóintézetben kialakult képzési forma adaptációja. 1994-ben az a JPTE Közgazdaságtudományi Kara Agrár-, Kömyezet- és Regionális-gazdaságtan Tanszékének és az MTA RKK DTI-nek az együttmükődésében kezdődött el a Regionális politika és gazdaságtan címmel a szakképzés a pécsi egyetemen, amelyben az Ipargazdaságtan Tanszék és a Természettudományi Karról az Általános Társadalomföldrajz és Urbanisztikai Tanszék is részt vesz. A posztgraduális és a nappali képzés pécsi tanterve volt a modellje a Gyóri Széchenyi István Fóiskolán, a Miskolci Egyetemen, és annak Dunaújvárosi Fóiskolai Karán beindult, valamint a Szegedi Egyetemen induló szakképzésnek. Hatással volt arra is, hogy a Pannon Agrártudományi Egyetem Gazdasági Mérnöki Szakán Kaposváron, a Regionális gazdaságtan kötelező tárgyként szerepel.

1996-ban akkreditáltuk a Regionális politika és gazdaságtan $\mathrm{PhD}$. programunkat és még ebben az évben PhD. szinten beindult a képzés. A PhD. program ugyancsak a RKK DTI, valamint az Agrár-, Környezet- és Regionális-gazdaságtan Tanszék kutatói és oktató állományára támaszkodik, de a képzésben már részt vesz a Közgazdaságtudományi Karról a: Gazdaságelméleti, Gazdaságinformatikai, Marketing, Ipargazdaságtan, Stratégiai Management Tanszék; a Jogtudományi Karról: a Nemzetközi Jogi Tanszék; a Természettudományi Karról: az Általános Társadalomföldrajz és Urbanisztikai Tanszék, valamint az MTA RKK Győri és Budapesti Intézete, a Budapesti Közgazdaságtudományi Egyetem Jövőkutatási Tanszéke és az Agrảrgazdasági Kutatóintézet, a Közgazdaságtudományi Intézet és az Ipargazdasági Kutató Intézet több kutatója is.

A történeti áttekintéssel kapcsolatban érdemes annyit megjegyezni, hogy a regionális politikai és gazdaságtani képzés három dátuma $(1989,1994,1996)$ döntỏ abból a szempontból, hogy az három szinten, a graduális, posztgraduális és $\mathrm{PhD}$. képzés szintjén egyidejüleg a magyarországi, de a volt szocialista régióban is az egyetemi képzés kezdetét jelentette. 


\section{A képzés eredményei, tapasztalatai}

\section{Végzettek száma, elhelyezkedése}

Graduális képzésben eddig 3 évfolyamon 27 fo, posztgraduális képzésben pedig 10 évfolyamon 120 fö szerzett diplomát.

A végzettek döntö többsége a minisztériumoknál, önkormányzatoknál, kamaráknál, területfejlesztéssel kapcsolatos kutató intézeteknél, Phare Irodáknál, regionális fejlesztéseket finanszirozó bankoknál dolgozik. Többen részt vesznek a Területfejlesztési Tanácsok munkájában is.

Eredmények között jegyzem meg, hogy három év alatt 4 hallgatónk nyert a diplomamunkájával díjat. Egy hallgatónk a KTM tanulmányi ösztöndiját kapta meg (Csató Péter), 2 hallgatónk (Mészáros Nóra, Novotny Gábor) miniszteri dicséretben részesưlt, egy hallgatónk (László Csaba) pedig az MTA PAB tudományos pályázatán nyert első díjat. Mi jelentett nehézséget?

- Nem volt hazai minta, minden programot elöször kellett elkészíteni.

- Nem volt kielégító a tananyag ellátottság - el kellett készíteni a tankönyveket.

- A rendelkezésre álló eszközpark (számítógépek, fénymásolok, fax stb.) hiánya nehézségeket okozott, föleg a $\mathrm{PhD}$. programok szervezésében.

- A tanárok és a hallgatók külföldi tapasztalatszerzésére minimálisak voltak a lehetöségek.

- A szak a hallgatók elött is ismeretlen volt és ezért kevés volt a jelentkezó.

A képzés fejlesztésében kiemelkedő szerepe volt a Párizs 8, a Leedsi és Las Palmasi Egyetemmel közösen 1995-ben elnyert „Training managers in regional development and European Cooperations" c. Tempus programnak. A program lehetőséget teremtett egyéni és kitủnően előkészített 10 napos csoportos szakmai tanulmányutak lebonyolítására, valamint az oktatás tárgyi feltételeinek a megteremtésére. A program által biztosított elönyők a következőkben foglalhatók össze:

Külföldi tapasztalatszerzés és továbbképzés, amely módot nyújtott:

- személyes konzultációkra oktatókkal, kutatókkal, gazdasági és önkormányzati szakemberekkel;

- a szakirodalom szinte teljes körü áttekintésére a partner egyetemek könyvtáraiban;

- konkrét fejlesztési tervek tanulmányozására és egyidejüleg megvalósult fejlesztések megtekintésére (Pompei, Leeds, Sheffield stb.);

- a nyelvi készség fejlesztésére.

\section{TÁBLÁZAT}

Külföldi úton résztvettek száma (Nancy, Párizs, Leeds, Las Palmas)

(Participants of Foreign Trip in Nancy, Paris, Leeds, Las Palmas)

\begin{tabular}{|l|c|c|c|}
\hline Megnevezés & 1996 & 1997 & 1998 \\
\hline Kutató + oktató & 15 & 15 & 16 \\
\hline Graduális hallgató & 5 & 7 & 7 \\
\hline Posztgraduális hallgató & $\mathbf{8}$ & 4 & 7 \\
\hline PhD. hallgató & - & 4 & 19 \\
\hline Ősszesen & 28 & 30 & 49 \\
\hline
\end{tabular}

Forrás: saját adatgyưjtés. 
Eredmények:

1. Minden nappali képzésben bekapcsolódó oktató részt vett valamelyik külföldi úton.

2. Minden föszakos nappali tagozatos hallgató volt legalább 10 napos külföldi gyakorlaton.

3. A 30 , jelenleg II. és III. éves PhD. hallgatóink közül 20 részt vett 10 naptól 3 hónapig terjedő szakmai úton a partner egyetemeken.

A több szakmai helyszín előnye volt, hogy lehetöséget nyújtott:

- a regionális fejlesztések eltérő súlypontjainak (Nancy-szolgáltatások, Leedsszolgáltatások, Las Palmas-turizmus, Sheffield ipar és szolgáltatások stb.),

- országonként eltérö intézményrendszereinek és

- eltérö finanszírozási feltételeinek megismerése.

A külföldi tanulmányutak és a fejlesztési tapasztalatok közvetlen megismerése - a hallgatók mellett - föleg a regionális tervezéssel korábban nem foglalkozók, de a szakon oktatók részére nyújtott rendkívül hasznos ismereteket. Lehetőség nyílt, külföldi egyetemek tanterveinek, képzési formáinak megismerésére; külföldi szakembereknek az oktatásba történő bekapcsolására. Eszközök beszerzésére sikerült a rendelkezésre álló keretből olyan mértékü gépbeszerzést megoldani, amely már teljes mértékben kielégíti a kutatás és az oktatás igényeit. (Beszerzésre került 8 számítógép, 2 fénymásoló, 1 scanner, 3 írásvetító, 1 fax, 4 nyomtató és nagyon sok könyv és folyóirat.) Tananyagok elkészítésére nagyon lényeges, hogy a szükséges tananyagok megírása már a külföldi tapasztalatok figyelembevételével történt, illetve történik. Eddig elkészült négy könyv, és három várhatóan az év során kiadásra kerül.

Külön előnyként könyveljük el, hogy az oktatás feltételeinek javulásával, valamint az elmúlt években szerzett kedvező tapasztalatok következtében ugrásszerüen megnött a hallgatók érdeklődése a szak iránt. Kezdetben nagyon nehéz volt egy új szakot elfogadtatni a sláger szakok, a management, bank és pénzügyek, illetve a marketing mellett. A hallgatók között kialakult az a vélemény, hogy ez az a szak, amely a felsőbb évfolyamokon is (a szakképzés a IV. és V. évfolyamon folyik) teljesen új ismereteket nyújt, lehetőséget biztosít külföldi és hazai tapasztalatok megszerzésére és a külfơldi oktatókkal és kutatókkal történő gyakori találkozásokra. A szak iránti érdeklődés növekedését nemcsak a főszakosok száma, de az is mutatja, hogy a más szakon hallgatók közül sokan végigtanulták ezt a szakot is, a szak egyes tárgyait felvevők száma pedig sokszor 4-5-szörösen meghaladta a föszakosok számát, az gyakran 30-40 fönél is több volt.

Regionális politika és gazdaságtan szak föszakos hallgatóinak száma

19945

19957

$1996 \quad 8$

$1997 \quad 8$

$1998 \quad 20$

\section{Az oktatás továbbfejlesztése}

A graduál képzésben az eddigi tapasztalatok figyelembevételével történik a szakképzés fejlesztése. Alapvető cél, hogy erösítsük az EU-val kapcsolatos ismeretek oktatását. Szakunkat egy olyan EU-s képzési iránynak tekintjük, amely konkrét szakismereteket is nyújt. Kihasználva a Közgazdaságtudományi Karon jelenleg 
folyó tantervi reformot, a Tempus program tapasztalatainak figyelembevételével a szakképzés tantervét a következőképpen fejlesztjük tovább.

\section{TÁBLÁZAT}

EU és Magyarország regionális politikája (Térségmanagement)

(Regional Politics of EU and Hungary)

\begin{tabular}{|l|l|l|}
\hline Regionális gazdaságtan & 2 óra & $\begin{array}{l}\text { dr. Hrubi László } \\
\text { tudományos fómunkatárs }\end{array}$ \\
\hline Terúletfejlesztés elmélete & 2 óra & $\begin{array}{l}\text { dr. Faragó László } \\
\text { tudományos fómunkatárs }\end{array}$ \\
\hline Centrum-periféria viszonya & 2 óra & $\begin{array}{l}\text { dr. Gazdag László } \\
\text { egyetemi adjunktus }\end{array}$ \\
\hline Európai regionális politika & 2 óra & $\begin{array}{l}\text { dr. Horváth Gyula } \\
\text { fóigazgató, PhD. }\end{array}$ \\
\hline Vidékpolitika & 2 óra & $\begin{array}{l}\text { dr.Buday-Sántha Attila } \\
\text { egyetemi tanár, DSc. }\end{array}$ \\
\hline Iparpolitika & 2 óra & $\begin{array}{l}\text { dr. Hoványi Gábor } \\
\text { egyetemi tanár, DSc. }\end{array}$ \\
\hline Helyi politika - Területi közigazgatás & 2 óra & $\begin{array}{l}\text { Pálné dr. Kovács Ilona } \\
\text { igazgató, PhD. }\end{array}$ \\
\hline Önkormányzatok gazdálkodása & 2 óra & $\begin{array}{l}\text { dr. László Mária } \\
\text { egyetemi docens, PhD. }\end{array}$ \\
\hline Regionális marketing & 2 óra & $\begin{array}{l}\text { Kraftné dr. Somogyi Gabriella } \\
\text { tudományos munkatárs }\end{array}$ \\
\hline Környezetvédelmi management & 2 óra & $\begin{array}{l}\text { dr. Buday-Sántha Attila } \\
\text { egyetemi tanár, DSc. }\end{array}$ \\
\hline EU intézményi és dőntési rendszer & 2 óra & $\begin{array}{l}\text { dr. Szalai Erzsébet } \\
\text { egyetemi adjunktus }\end{array}$ \\
\hline Management & 2 óra & $\begin{array}{l}\text { dr. Hanyecz Lajos } \\
\text { egyetemi docens, PhD. }\end{array}$ \\
\hline Transzeurópai hálózatok és a regionalizmus & 2 óra & $\begin{array}{l}\text { dr. Erdősi Ferenc } \\
\text { egyetemi tanár, DSc. }\end{array}$ \\
\hline Település szociológia & $\begin{array}{l}\text { dr. Kovács Teréz } \\
\text { tudományos fömunkatárs, PhD. }\end{array}$ \\
\hline Szakszeminárium & óra & ón \\
\hline
\end{tabular}

Ezzel egyidejüleg sor kerül minden tárgy ismeretanyagának megvitatására, és ez alapján az új tematikájának az elkészítésére.

A posztgraduális képzésre ebben az évben nem volt beiskolázás. Az RKK kutatói az „Európai regionális fejlesztés és kohéziós politika” címmel teljesen új tantervet készítettek, amely a korábbi 2 éves képzés helyett 7 tárgyra: Európai politikai földrajz, Európai regionális politikák ősszehasonlító elemzése, A transzeurópai hálózatok regionális hatásai, Regionális kőzigazgatás és szervezetrendszer, Vidékfejlesztés, Európai területi tervezés, Helyi gazdaságfejlesztés és partnerkapcsolatok, alapozottan féléves intenzív képzéseket kíván megvalósítani, amelynek részét képezné egy szabadon választott világnyelv oktatása is.

A PhD. képzésünkben ebben az évben fejezi be az elsỏ beiskolázott évfolyam a 3 éves tanulmányait. A tapasztalatok értékelése ezután következhet. Az már ma is látható, hogy a tervezett program teljesíthetó és a kutatómunkához kellő segítséget 
tud nyújtani. Ebben jelentós szerepe van az MTA Regionális Kutatások Központjával való együttmúködésnek, amely biztosítani tudja azt is, hogy a hallgatókat nagy számban tudjuk bekapcsolni a kutató intézeteiben folyó kutató munkákba. A PhD. programunk iránt folyamatosan nó az érdeklődés, amit az alábbi adatok is igazolnak.

\section{TÁBLÁZAT}

Regionális politika és gazdaságtan $P h D$. program hallgatóinak száma (Number of Students in Regional Politics and Economics PhD. program)

\begin{tabular}{|l|c|c|}
\hline \multicolumn{1}{|c|}{ Évfolyam } & Jelentkezök száma & Jelenlegi létszám \\
\hline I. évf. & 31 & 28 \\
\hline II. évf. & 24 & 18 \\
\hline III. évf. & 18 & 9 \\
\hline Tanulmányait szünetelteti & - & 2 \\
\hline Összesen: & 73 & 57 \\
\hline
\end{tabular}

A PhD. képzésre csak egyetemi diplomával rendelkező szakemberek jelentkezhetnek. A képzési programra felvettek többsége már hosszú ideje dolgozik a szakmájában. Így már kellö tapasztalatok birtokában az egyetemi hallgatóknál is jobban meg tudják itélni a szak újszerüségét, az általa nyújtott ismeretek fontosságát, amit a jelentkezők magas száma is tükröz.

Jövő évben egy éves beiskolázási szünetet fogunk tartani, hogy a védések lebonyolitására több figyelmet tudjunk fordítani. A programunkban egy egyéni képzési programban résztvevỏ hallgató (dr. László Mária) védésére ez év tavaszán került sor és ezzel megkezdỏdött a tudományos fokozatok kiadása.

Összefoglalóan a JPTE Közgazdaságtudományi Kara Agrár-, Környezet- és Regionális-gazdaságtan Tanszékének és az MTA RKK kutatóintézeteinek együttmüködésében, a JPTE más tanszékeinek, továbbá több kutatóintézet vezetó kutatóinak bevonásával Pécsett sikerült egy újszerú és a kor kővetelményeinek megfelelö képzési formát kialakítani graduális, posztgraduális és $\mathrm{PhD}$. szinten egyaránt. A képzés feltételeinek megteremtésében a három külföldi egyetemmel közösen elnyert Tempus program, döntő szerepet játszott. A regionális fejlesztési igények növekedésével, az EU-hoz való csatlakozással egyidejüleg ugrásszerủen megnő a kereslet a regionális tudományokban jártas szakemberek iránt. Ezért szükség van arra is, hogy a magyar közéletben tudatosuljon az, hogy az országban már képeznek ilyen felkészuiltségü szakembereket. 